\title{
Spectroscopic, structure and DFT studies of palladium(II) complexes with pyridine-type ligands
}

\author{
J. G. Małecki · Anna Maroń
}

Received: 1 January 2011 / Accepted: 2 February 2011/Published online: 19 February 2011

(C) The Author(s) 2011. This article is published with open access at Springerlink.com

\begin{abstract}
Five palladium(II) complexes with pyridine derivative ligands have been synthesized. The molecular structures of the complexes were determined by X-ray crystallography, and their spectroscopic properties were studied. Based on the crystal structures, computational investigations were carried out in order to determine the electronic structures of the complexes. The electronic spectra were calculated with the use of time-dependent DFT methods, and the electronic spectra of the transitions were correlated with the molecular orbitals of the complexes. The emission properties of the complexes have been examined.
\end{abstract}

\section{Introduction}

Palladium(II) complexes currently attract a considerable interest because of their potentially beneficial pharmacological properties. Palladium complexes with aromatic $\mathrm{N}$-containing ligands, e.g., derivatives of pyridine, quinoline, pyrazole, and 1,10-phenanthroline, have shown very promising antitumor characteristics [1-4]. Some of these complexes, especially the trans analogs with nonplanar heterocyclic amine ligands, have been found to overcome multifactorial cisplatin resistance in human ovarian cell lines $[5,6]$. On the other hand, $\mathrm{Pd}(\mathrm{II})$ complexes have been widely explored due to their catalytic efficiency, e.g., for

The Gaussian09 calculations were carried out in Wrocław Centre for Networking and Supercomputing, WCSS, Wrocław, Poland.

J. G. Małecki ( $\bowtie) \cdot$ A. Maroń

Department of Crystallography, Institute of Chemistry,

University of Silesia, 9th Szkolna St., 40-006 Katowice, Poland

e-mail: gmalecki@us.edu.pl various carbon-carbon and carbon-nitrogen bond-forming reactions [7-11]. While most studies of palladium have concentrated on the reactivity of its complexes, little information about their electronic structures has been obtained.

Complexes with pyridine derivative ligands and such metals as ruthenium(II), osmium(II), and rhenium(I) are by far the most studied due to their luminescent properties. In contrast, $d^{8}$ metal complexes have been much less studied. The luminescent properties of palladium(II) complexes strongly depend on their electronic structure. For this reason, study of the electronic structures of such complexes is valuable as a means to the prediction of their properties [12].

In this paper, we present the synthesis, crystal, molecular, electronic structures, and the spectroscopic characterization of five palladium(II) complexes with pyridine-type ligands. The electronic structures of the complexes have been determined by density functional theory (DFT) and employed for the discussion of bonding properties.

\section{Experimental}

All reagents used for the synthesis of the complexes were commercial products and have been used without further purification.

Synthesis of $\left[\mathrm{PdCl}_{2}(\mathrm{~L})_{2}\right]$ complexes

A typical procedure for the preparation of the complexes is as follows: a solution of $\mathrm{PdCl}_{2}(0.177 \mathrm{~g}, 0.1 \mathrm{mmol})$ and 2-hydroxy6-methylpyridine (1) ( $0.22 \mathrm{~g}, 0.2 \mathrm{mmol})$, 2-aminomethylpyridine (2) $\left(0.2 \mathrm{~cm}^{-3}, 0.2 \mathrm{mmol}\right), 2$-hydroxypropylpyridine (3) $\left(0.28 \mathrm{~cm}^{-3}, 0.2 \mathrm{mmol}\right), 2$-benzoilpyridine (4) (0.36 g, 
$0.2 \mathrm{mmol})$, or 4-(3-phenylpropyl)pyridine (5) $\left(0.4 \mathrm{~cm}^{-3}\right.$, $0.2 \mathrm{mmol})$ in acetonitrile $\left(50 \mathrm{~cm}^{3}\right)$ was refluxed for about $2 \mathrm{~h}$ and than filtered. Crystals suitable for X-ray analysis were obtained by slow evaporation of solvent.

1: IR (KBr) $\left[\mathrm{cm}^{-1}\right]: 3,400 v_{\mathrm{OH}} ; 3,163 v_{\mathrm{ArH}} ; 2,917 v_{\mathrm{CH}}$; $1,614 v_{\mathrm{C}=\mathrm{N}} ; 1,578 v_{\mathrm{C}=\mathrm{C}} ; 1,452,1,306 \delta_{(\mathrm{C}-\mathrm{CH}}$ in the plane $)$; $1,434 v_{\mathrm{Ph}} ; 1,099,1,037 \delta_{\mathrm{OH}} ; 788 \delta_{(\mathrm{C}-\mathrm{C} \text { out of the plane })} ; 742$ $\delta_{(\mathrm{C}-\mathrm{C} \text { out of the plane) }}{ }^{1} \mathrm{H}$ NMR $[\delta, \mathrm{ppm}]:\left(\mathrm{DMSO}-d^{6}\right): 7.743$, 7.303 (py), $6.095(\mathrm{OH}), 2.152\left(\mathrm{CH}_{3}\right)$. UV-VIS $[\lambda \mathrm{nm},(\varepsilon)]$ (acetonitrile): 417 (1.21), 305 (2.14), 280 (2.21), 236 (4.87), 202 (4.37).

2: IR (KBr) $\left[\mathrm{cm}^{-1}\right]: 3,330 v_{\mathrm{NH}} ; 3,060,3,022 v_{\mathrm{ArH}}$; 2,942, 2,883 $v_{\mathrm{CH}} ; 1,605 v_{\mathrm{C}=\mathrm{N}} ; 1,583 v_{\mathrm{C}=\mathrm{C}} ; 1,480,1,247$ $\delta_{(\mathrm{C}-\mathrm{CH}}$ in the plane) $; 1,444 v_{\mathrm{Ph}} ; 1,060,1,022 \delta_{\mathrm{NH}} ; 922$ $\delta_{(\mathrm{C}-\mathrm{H} \text { out of the plane })} ; 804 \delta_{(\mathrm{C}-\mathrm{C} \text { out of the plane })} ; 702 \delta_{(\mathrm{C}-\mathrm{C} \text { out of }}$ the plane). ${ }^{1} \mathrm{H}$ NMR $[\delta, \mathrm{ppm}]:\left(\mathrm{DMSO}-d^{6}\right): 9.012,7.743$, 7.723 (py), 4.169 (NH), $1.597\left(\mathrm{CH}_{2}\right)$. UV-VIS $[\lambda \mathrm{nm}(\varepsilon)]$ (acetonitrile): 370 (1.98), 319 (2.17), 255 (4.75), 211 (4.88).

3: IR $(\mathrm{KBr})\left[\mathrm{cm}^{-1}\right]$ : $3,485 v_{\mathrm{OH}} ; 3,070 v_{\mathrm{ArH}} ; 2,919$, $2,874,2,788 v_{\mathrm{CH}} ; 1,607 v_{\mathrm{C}=\mathrm{N}} ; 1,570 v_{\mathrm{C}=\mathrm{C}} ; 1,482,1,260$ $\delta_{(\mathrm{C}-\mathrm{CH}}$ in the plane $) ; 1,453 v_{\mathrm{Ph}} ; 1,073,1,052 \delta_{\mathrm{OH}} ; 917$ $\delta_{(\mathrm{C}-\mathrm{H} \text { out of the plane })} ; 768 \delta_{(\mathrm{C}-\mathrm{C} \text { out of the plane })} ; 749 \delta_{(\mathrm{C}-\mathrm{C} \text { out of }}$ the plane). ${ }^{1} \mathrm{H}$ NMR $[\delta, \mathrm{ppm}]:\left(\mathrm{DMSO}-d^{6}\right): 8.322,8.031$, 7.369 (py), $5.172(\mathrm{OH}), 4.171(\mathrm{t}), 3.812,2.029\left(\mathrm{CH}_{2}\right)$. UV-VIS [ $\lambda \mathrm{nm},(\varepsilon)$ ] (acetonitrile): 392 (1.83), 319 (2.06), 265 (3.96), 232 (4.13), 212 (4.97).

4: IR (KBr) $\left[\mathrm{cm}^{-1}\right]: 3,082,3,050 v_{\mathrm{ArH}} ; 1,676 v_{\mathrm{C}=\mathrm{O}} ; 1,595$ $v_{\mathrm{C}=\mathrm{N}} ; 1,566 v_{\mathrm{C}=\mathrm{C}} ; 1,446 v_{\mathrm{Ph}} ; 1,318,1,283,1,160 \delta_{\mathrm{C}=\mathrm{O}} ; 943$, $928 ; 917 \delta_{(\mathrm{C}-\mathrm{H} \text { out of the plane })} ; 776 \delta_{(\mathrm{C}-\mathrm{C} \text { out of the plane })} ; 706$ $\delta_{(\mathrm{C}-\mathrm{C} \text { out of the plane) }}{ }^{1} \mathrm{H}$ NMR $[\delta, \mathrm{ppm}]:\left(\mathrm{DMSO}-d^{6}\right): 9.027$, 8.049, 7.880, 7.719, 7.616, 7.469 (py, Ph). UV-VIS [ $\lambda$ nm, (ع)] (acetonitrile): 370 (1.62), 262 (3.97), 237 (4.17), 211 (5.06).

5: $\mathrm{IR}(\mathrm{KBr})\left[\mathrm{cm}^{-1}\right]: 3,070 v_{\mathrm{ArH}} ; 2,918,2,858 v_{\mathrm{CH}} ; 1,618$ $v_{\mathrm{C}=\mathrm{N}} ; 1,578 v_{\mathrm{C}=\mathrm{C}} ; 1,490,1,267 \delta_{(\mathrm{C}-\mathrm{CH}}$ in the plane $) ; 1,452 v_{\mathrm{Ph}}$; $918 \delta_{(\mathrm{C}-\mathrm{H}}$ out of the plane $) ; 756 \delta_{(\mathrm{C}-\mathrm{C} \text { out of the plane })} ; 706$ $\delta_{\text {(C-C out of the plane) }}{ }^{1} \mathrm{H}$ NMR $[\delta, \mathrm{ppm}]:\left(\mathrm{DMSO}-d^{6}\right): 8.823$, 7.102 (py), 7.461-6.952 (Ph), 2.628, $1.973\left(\mathrm{CH}_{2}\right)$. UV-VIS [ $\lambda \mathrm{nm},(\varepsilon)]$ (acetonitrile): 377 (1.23), 285 (2.96), 212 (4.95).

Physical measurements and DFT calculations

Infrared spectra were recorded on a Nicolet Magna 560 spectrophotometer in the range of $4,000-450 \mathrm{~cm}^{-1}$ using $\mathrm{KBr}$ pellets. Electronic spectra were measured on a Lab Alliance UV-VIS 8,500 spectrophotometer in the range of 1,100-180 nm in methanol solution. ${ }^{1} \mathrm{H}$ NMR spectra were obtained at room temperature in $\mathrm{CDCl}_{3}$ using a Bruker 400 spectrometer.

The calculations were carried out using the Gaussian09 [13] program. The DFT/B3LYP [14, 15] method was used for the geometry optimization and electronic structure determination. The electronic spectra were calculated by the TD-DFT [16] method with use of the CAM-B3LYP functional [17]. The calculations were performed using the DZVP basis set [18] with $\mathrm{f}$ functions with exponents 1.94722036 and 0.748930908 on palladium and polarization functions for all other atoms: $6-31 \mathrm{G}^{* *}$ for chlorine, carbon, nitrogen and 6-31G for hydrogen. The PCM solvent model was used in the Gaussian calculations with acetonitrile as the solvent. Natural bond orbital (NBO) calculations were performed with the NBO code [19] included in Gaussian09. GaussSum 2.2 [20] was used to calculate group contributions to the molecular orbitals and to prepare the partial density of states (DOS) and overlap population density of states (OPDOS) spectra. The contribution of a group to a molecular orbital was calculated using Mulliken population analysis. The PDOS and OPDOS spectra were created by convoluting the molecular orbital information with Gaussian curves of unit height and FWHM of $0.3 \mathrm{eV}$.

Crystal structures determination and refinement

Yellow crystals of $\left[\mathrm{PdCl}_{2}\left(\mathrm{CH}_{3} \mathrm{pyOH}\right)_{2}\right](\mathbf{1}),\left[\mathrm{PdCl}_{2}\left(\mathrm{pyCH}_{2}-\right.\right.$ $\left.\left.\left.\mathrm{NH}_{2}\right)_{2}\right](2),\left[\mathrm{PdCl}_{2}\left(\mathrm{py}\left(\mathrm{CH}_{2}\right)_{3} \mathrm{OH}\right)_{2}\right](3),\left[\mathrm{PdCl}_{2} \text { (bopy) }\right)_{2}\right](4)$, and $\left[\mathrm{PdCl}_{2}(\mathrm{pyCHPh})_{2}\right]$ (5) were mounted in turn on an Xcalibur, Atlas, Gemini ultra Oxford Diffraction automatic diffractometer equipped with a CCD detector, and used for data collection. X-ray intensity data were collected with graphite monochromated $\operatorname{Mo} K \alpha$ radiation $(\lambda=0.71073 \AA)$ at a temperature of 295.0(2) K, with $\omega$ scan mode. Ewald sphere reflections were collected up to $2 \theta=50.10^{\circ}$. The unit cell parameters were determined from least-squares refinement of the setting angles of 2,839, 4,094, 6,556, 6,894 , and 6,541 strongest reflections. The details concerning crystal data and refinement are gathered in Table 1. During the data reduction, the decay correction coefficients were taken into account. Lorentz, polarization, and numerical absorption corrections were applied. The structures were solved by Patterson methods. All the nonhydrogen atoms were refined anisotropically using fullmatrix, least-squares techniques on $F^{2}$. All the hydrogen atoms were found from difference Fourier synthesis after four cycles of anisotropic refinement and refined as "riding" on the adjacent atoms with individual isotropic temperature factor equal 1.2 times the value of equivalent temperature factor of the parent atom, with geometry idealization after each cycle. The Olex2 [21] and SHELXS97 [22], SHELXL97 [23] programs were used for all the calculations. Atomic scattering factors were those incorporated in the computer programs. 
Table 1 Crystal data and structure refinement details of $\left[\mathrm{PdCl}_{2}\left(\mathrm{CH}_{3} \mathrm{pyOH}\right)_{2}\right](\mathbf{1}), \quad\left[\mathrm{PdCl}_{2}\left(\mathrm{pyCH}_{2} \mathrm{NH}_{2}\right)_{2}\right](2),\left[\mathrm{PdCl}{ }_{2}\left(\mathrm{py}\left(\mathrm{CH}_{2}\right)_{3} \mathrm{OH}\right)_{2}\right](3)$, $\left[\mathrm{PdCl}_{2}(\text { bopy })_{2}\right](4)$, and $\left[\mathrm{PdCl}_{2}(\mathrm{pyCHPh})_{2}\right](5)$ complexes

\begin{tabular}{|c|c|c|c|c|c|}
\hline & 1 & 2 & 3 & 4 & 5 \\
\hline Empirical formula & $\mathrm{C} 12 \mathrm{H} 14 \mathrm{Cl} 2 \mathrm{~N} 2 \mathrm{O} 2 \mathrm{Pd}$ & $\mathrm{C} 12 \mathrm{H} 16 \mathrm{Cl} 2 \mathrm{~N} 4 \mathrm{Pd}$ & $\mathrm{C} 16 \mathrm{H} 22 \mathrm{Cl} 2 \mathrm{~N} 2 \mathrm{O} 2 \mathrm{Pd}$ & $\mathrm{C} 24 \mathrm{H} 18 \mathrm{Cl} 2 \mathrm{~N} 2 \mathrm{O} 2 \mathrm{Pd}$ & $\mathrm{C} 28 \mathrm{H} 30 \mathrm{Cl} 2 \mathrm{~N} 2 \mathrm{Pd}$ \\
\hline Formula weight & 395.55 & 393.59 & 451.66 & 543.70 & 571.84 \\
\hline Temperature $[\mathrm{K}]$ & 295.0(2) K & 295.0(2) K & 295.0(2) K & 295.0(2) K & 295.0(2) K \\
\hline Crystal system & Monoclinic & Triclinic & Monoclinic & Monoclinic & Monoclinic \\
\hline Space group & $\mathrm{C} 2 / \mathrm{c}$ & $\mathrm{P}-1$ & $\mathrm{P} 2{ }_{1} / \mathrm{c}$ & $\mathrm{P} 2{ }_{1} / \mathrm{c}$ & $\mathrm{P} 2{ }_{1} / \mathrm{n}$ \\
\hline \multicolumn{6}{|l|}{ Unit cell dimensions } \\
\hline$a[\AA]$ & $15.805(5)$ & $4.1549(11)$ & $8.3214(7)$ & 7.7004(4) & $7.1248(4)$ \\
\hline$b[\AA]$ & $6.7909(16)$ & $8.4001(14)$ & $13.8284(8)$ & $8.5655(3)$ & $21.8066(11)$ \\
\hline$c[\AA]$ & $14.265(11)$ & $10.2093(18)$ & $8.7294(8)$ & $17.2889(9)$ & $8.8244(6)$ \\
\hline$\alpha$ & 90 & $91.915(14)$ & 90 & 90 & 90 \\
\hline$\beta$ & 108.02(6) & $93.408(17)$ & $117.780(11)$ & $100.871(6)$ & $109.404(7)$ \\
\hline$\gamma$ & 90 & $101.552(18)$ & 90 & 90 & 90 \\
\hline Volume $\left[\AA^{3}\right]$ & $1,456.0(13)$ & $348.11(13)$ & $888.73(15)$ & $1,119.88(10)$ & $1,293.14(13)$ \\
\hline $\mathrm{Z}$ & 4 & 1 & 2 & 2 & 2 \\
\hline Calculated density $\left[\mathrm{Mg} / \mathrm{m}^{3}\right]$ & 1.804 & 1.877 & 1.688 & 1.612 & 1.469 \\
\hline $\begin{array}{l}\text { Absorption coefficient } \\
{\left[\mathrm{mm}^{-1}\right]}\end{array}$ & 1.639 & 1.707 & 1.354 & 1.091 & 0.943 \\
\hline $\mathrm{F}(000)$ & 784 & 196 & 456 & 544 & 584 \\
\hline Crystal dimensions $[\mathrm{mm}]$ & $0.11 \times 0.08 \times 0.03$ & $0.18 \times 0.08 \times 0.06$ & $0.49 \times 0.13 \times 0.10$ & $0.19 \times 0.12 \times 0.11$ & $0.23 \times 0.13 \times 0.04$ \\
\hline $\begin{array}{l}\theta \text { range for data } \\
\text { collection }\left[{ }^{\circ}\right]\end{array}$ & $3.37-25.04$ & $4.00-25.04$ & $3.96-25.04$ & $3.38-25.05$ & $3.56-25.05$ \\
\hline Index ranges & $\begin{array}{l}-18 \leq h \leq 18 \\
-8 \leq k \leq 5 \\
-16 \leq l \leq 16\end{array}$ & $\begin{array}{l}-4 \leq h \leq 4 \\
-9 \leq k \leq 9 \\
-12 \leq l \leq 12\end{array}$ & $\begin{array}{l}-9 \leq h \leq 9 \\
-16 \leq k \leq 16 \\
-10 \leq l \leq 10\end{array}$ & $\begin{array}{l}-9 \leq h \leq 9 \\
-10 \leq k \leq 10 \\
-20 \leq l \leq 20\end{array}$ & $\begin{array}{l}-8 \leq h \leq 8 \\
-25 \leq k \leq 25 \\
-10 \leq l \leq 10\end{array}$ \\
\hline Reflections collected & 4,342 & 5,898 & 8,310 & 10,025 & 11,451 \\
\hline Independent reflections & $\begin{array}{l}1,287 \\
{\left[R\left({ }_{\text {int }}\right)=0.0377\right]}\end{array}$ & $\begin{array}{l}1,215 \\
{\left[R\left({ }_{\text {int }}\right)=0.0586\right]}\end{array}$ & $\begin{array}{l}1,574 \\
\quad\left[R\left({ }_{\text {int }}\right)=0.0239\right]\end{array}$ & $\begin{array}{l}1,958 \\
\quad\left[R\left({ }_{\text {int }}\right)=0.0914\right]\end{array}$ & $\begin{array}{l}2,287 \\
\quad\left[R\left({ }_{\text {int }}\right)=0.0679\right]\end{array}$ \\
\hline Data/restraints/parameters & $1,287 / 0 / 90$ & $1,215 / 0 / 94$ & $1,574 / 0 / 107$ & $1,958 / 0 / 143$ & $2,287 / 0 / 151$ \\
\hline Goodness-of-fit on $F^{2}$ & 0.963 & 1.051 & 1.065 & 1.044 & 1.039 \\
\hline Final $\mathrm{R}$ indices $[I>2 \sigma(I)]$ & $\begin{array}{l}R_{1}=0.0279 \\
w R_{2}=0.0625\end{array}$ & $\begin{array}{l}R_{1}=0.0362 \\
w R_{2}=0.0934\end{array}$ & $\begin{array}{l}R_{1}=0.0195 \\
w R_{2}=0.0530\end{array}$ & $\begin{array}{l}R_{1}=0.0540 \\
w R_{2}=0.1328\end{array}$ & $\begin{array}{l}R_{1}=0.0289 \\
w R_{2}=0.0720\end{array}$ \\
\hline$R$ indices (all data) & $\begin{array}{l}R_{1}=0.0382 \\
w R_{2}=0.0644\end{array}$ & $\begin{array}{l}R_{1}=0.0381 \\
w R_{2}=0.0943\end{array}$ & $\begin{array}{l}R_{1}=0.0235 \\
w R_{2}=0.0541\end{array}$ & $\begin{array}{l}R_{1}=0.0640 \\
w R_{2}=0.1380\end{array}$ & $\begin{array}{l}R_{1}=0.0379 \\
w R_{2}=0.0742\end{array}$ \\
\hline Largest diff. peak and hole & 0.494 and -0.427 & 0.888 and -0.482 & 0.607 and -0.264 & 1.960 and -1.218 & 0.260 and -0.518 \\
\hline
\end{tabular}

\section{Results and discussion}

Palladium(II) complexes with pyridine derivative ligands were obtained by reactions of $\mathrm{PdCl}_{2}$ with 2-hydroxyl-6methylpyridine (1), 2-aminomethylpyridine (2), 2-hydroxypropylpyridine (3), 2-benzoilpyridine (4), or 4-(3-phenylpropyl)pyridine (5) in acetonitrile solutions. In the IR spectra of the complexes, the ring $\mathrm{C}=\mathrm{N}$ and $\mathrm{C}=\mathrm{C}$ stretching modes of the pyridine-type ligands are present at 1,595$1,618 \mathrm{~cm}^{-1}$ and $1,583-1,566 \mathrm{~cm}^{-1}$, respectively. The stretching and bending modes of the $\mathrm{OH}$ and $\mathrm{NH}_{2}$ group in complexes 1, 2, and $\mathbf{3}$ have maxima at 3,330-3,400 $\mathrm{cm}^{-1}$, 1,099-1,037, and 1,060-1,022 $\mathrm{cm}^{-1}$ in complexes $\mathbf{1}, \mathbf{3}$, and
2, respectively. The $\mathrm{C}=\mathrm{O}$ stretching mode of 2-benzoilpyridine in complex 4 is present at $1,676 \mathrm{~cm}^{-1}$ which confirms coordination number 4 in the complex. The ${ }^{1} \mathrm{H} N M R$ spectra of the complexes display the expected signals from the ligands. The signals of the hydroxyl and ammine protons are present at 6.095, 5.172, and $4.169 \mathrm{ppm}$ in complexes (1), (3), and (2), respectively.

\section{Crystal structures}

The complexes crystallize in the space groups given in Table 1. The molecular structures of the complexes are shown in Fig. 1. Selected bond lengths and angles are 
Fig. 1 ORTEP drawing of $\left[\mathrm{PdCl}_{2}\left(\mathrm{CH}_{3} \mathrm{pyOH}\right)_{2}\right](\mathbf{1})$, $\left[\mathrm{PdCl}_{2}\left(\mathrm{pyCH}_{2} \mathrm{NH}_{2}\right)_{2}\right]$ (2), $\left[\mathrm{PdCl}_{2}\left(\mathrm{py}\left(\mathrm{CH}_{2}\right)_{3} \mathrm{OH}\right)_{2}\right](\mathbf{3})$, $\left.\left[\mathrm{PdCl}_{2} \text { (bopy) }\right)_{2}\right](4)$, and $\left[\mathrm{PdCl}_{2}(\mathrm{pyCHPh})_{2}\right](\mathbf{5})$ complexes with $50 \%$ probability displacement ellipsoids
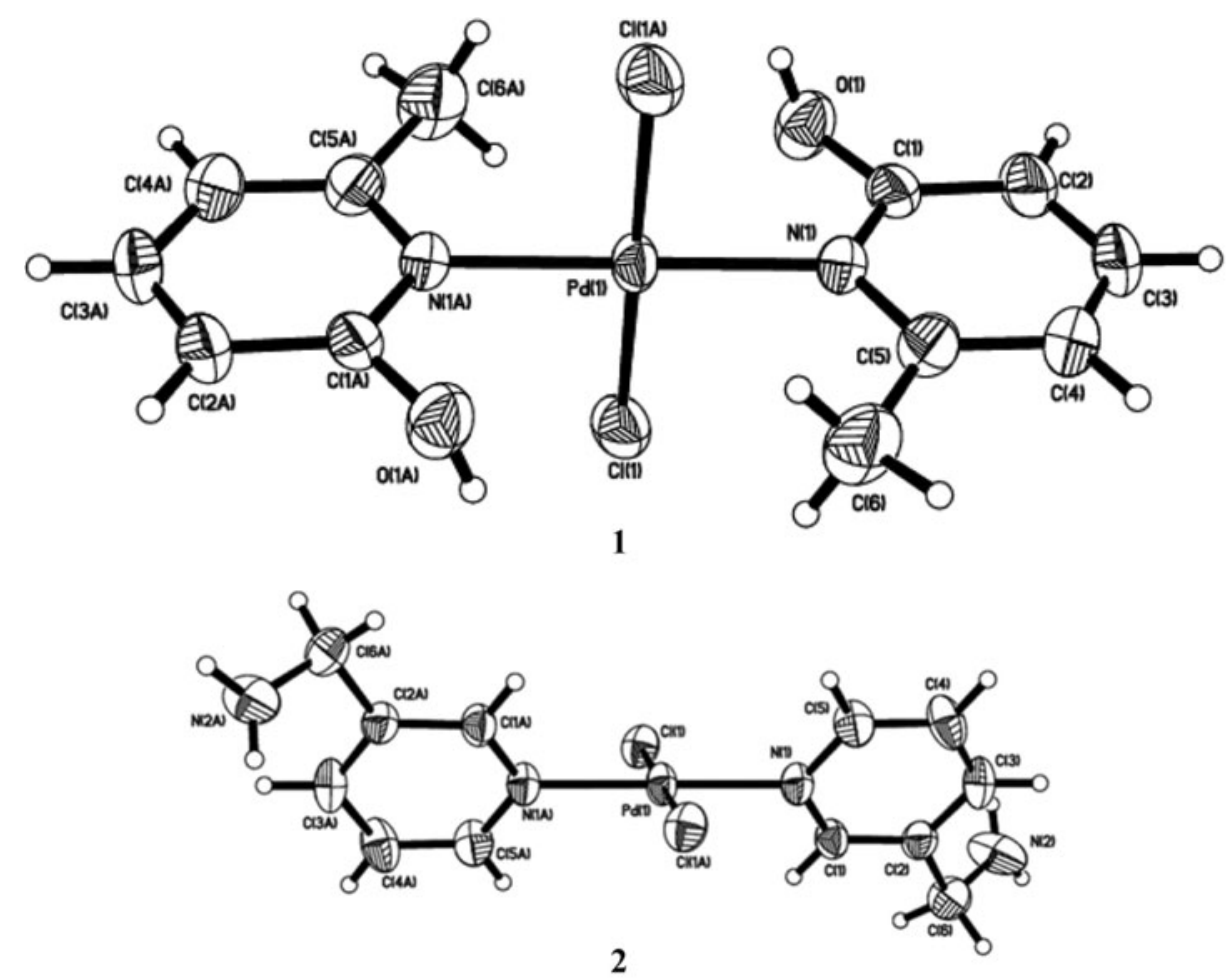

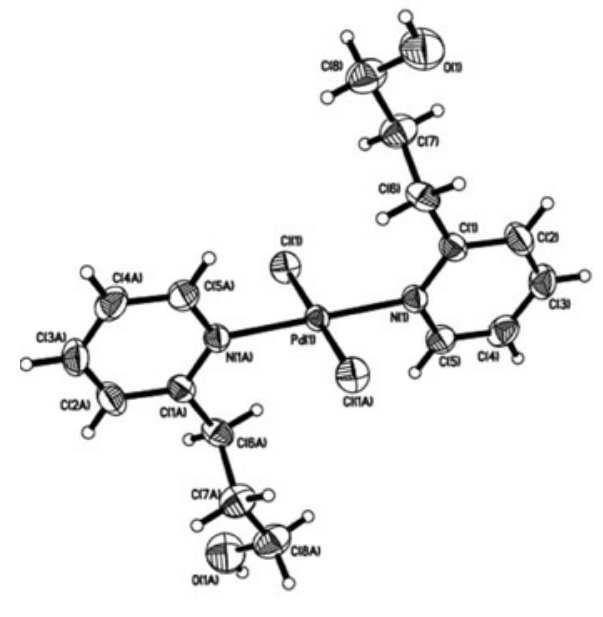

3
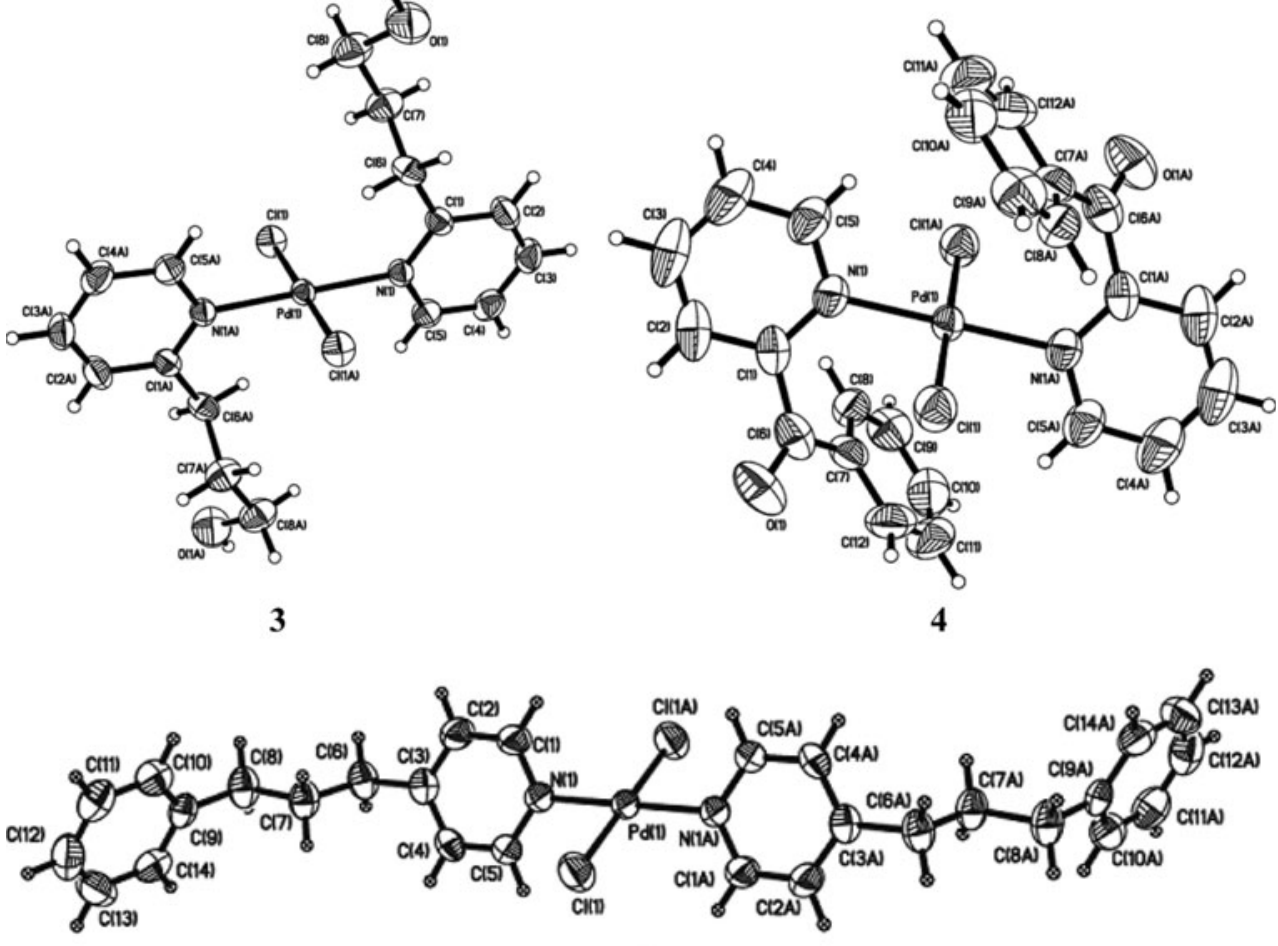

5

listed in Table 2. The palladium(II) atoms in these complexes have square planar environments with the ligands bonded to the metal centre through the pyridine nitrogen atoms. The $\mathrm{Pd}-\mathrm{N}_{(\mathrm{py})}$ and $\mathrm{Pd}-\mathrm{Cl}$ distances are similar and comparable with other palladium(II) complexes. The conformations of molecules of $\mathbf{2}$ and $\mathbf{3}$ are stabilized by interand intramolecular hydrogen bonds as collected in Table 3 . In Fig. 2, the crystal packing of complex 2 viewing down 
Table 2 Selected bond lengths $[\AA]$ and angles $\left[^{\circ}\right]$ for $\left[\mathrm{PdCl}_{2}\left(\mathrm{CH}_{3} \mathrm{pyOH}\right)_{2}\right](\mathbf{1}),\left[\mathrm{PdCl}_{2}\left(\mathrm{pyCH}_{2} \mathrm{NH}_{2}\right)_{2}\right](\mathbf{2}),\left[\mathrm{PdCl}{ }_{2}\left(\mathrm{py}\left(\mathrm{CH}_{2}\right)_{3} \mathrm{OH}\right)_{2}\right](\mathbf{3})$, $\left[\mathrm{PdCl}_{2}(\text { bopy })_{2}\right](\mathbf{4})$, and $\left[\mathrm{PdCl}_{2}(\mathrm{pyCHPh})_{2}\right](\mathbf{5})$ with the optimized geometry values

\begin{tabular}{|c|c|c|c|c|c|c|c|c|c|c|}
\hline & \multicolumn{2}{|l|}{1} & \multicolumn{2}{|l|}{2} & \multicolumn{2}{|l|}{3} & \multicolumn{2}{|l|}{4} & \multicolumn{2}{|l|}{5} \\
\hline & Exp & Calc & Exp & Calc & $\operatorname{Exp}$ & Calc & Exp & Calc & Exp & Calc \\
\hline \multicolumn{11}{|l|}{ Bond lengths $[\AA]$} \\
\hline $\operatorname{Pd}(1)-\mathrm{N}(1)$ & $2.027(3)$ & 1.945 & $2.014(4)$ & 2.093 & $2.014(4)$ & 2.103 & $2.027(16)$ & 2.103 & $2.024(2)$ & 2.358 \\
\hline $\operatorname{Pd}(1)-C l(1)$ & $2.320(16)$ & 2.411 & $2.321(13)$ & 2.416 & $2.321(13)$ & 2.379 & $2.3118(6)$ & 2.379 & $2.295(7)$ & 1.914 \\
\hline \multicolumn{11}{|l|}{ Angles $\left[{ }^{\circ}\right]$} \\
\hline $\mathrm{N}(1)-\mathrm{Ru}(1)-\mathrm{Cl}(1)$ & $90.05(9)$ & 90.43 & $90.27(10)$ & 90.51 & $90.27(11)$ & 90.40 & $89.34(5)$ & 90.41 & $90.39(6)$ & 94.07 \\
\hline
\end{tabular}

Table 3 Hydrogen bonds for $\left[\mathrm{PdCl}_{2}\left(\mathrm{pyCH}_{2} \mathrm{NH}_{2}\right)_{2}\right](2),\left[\mathrm{PdCl}_{2}(\mathrm{py}\right.$ $\left.\left.\left(\mathrm{CH}_{2}\right)_{3} \mathrm{OH}\right)_{2}\right](\mathbf{3})$, and $\left[\mathrm{PdCl}_{2}(\mathrm{pyCHPh})_{2}\right](\mathbf{5})\left(\AA\right.$ and $\left.{ }^{\circ}\right)$

\begin{tabular}{lllll}
\hline $\mathrm{D}-\mathrm{H} \cdots \mathrm{A}$ & $\mathrm{d}(\mathrm{D}-\mathrm{H})$ & $\mathrm{d}(\mathrm{H} \cdots \mathrm{A})$ & $\mathrm{d}(\mathrm{D} \cdots \mathrm{A})$ & $<(\mathrm{DHA})$ \\
\hline $\mathbf{2}$ & & & & \\
$\mathrm{N}(2)-\mathrm{H}(2 \mathrm{~B}) \cdots \mathrm{Cl}(1) \# 1$ & $0.837(19)$ & $2.38(2)$ & $3.191(4)$ & $164(5)$ \\
$\mathbf{3}$ & & & & \\
$\mathrm{C}(6)-\mathrm{H}(6 \mathrm{~B}) \cdots \mathrm{O}(1)$ & 0.97 & 2.58 & $2.915(3)$ & 100.1 \\
$\mathrm{O}(1)-\mathrm{H}(1) \cdots \mathrm{Cl}(1) \# 2$ & 0.82 & 2.46 & $3.2502(19)$ & 162.7 \\
$\mathbf{5}$ & & & & \\
$\mathrm{C}(5)-\mathrm{H}(4) \cdots \mathrm{Cl}(1)$ & 0.93 & 3.03 & $3.328(3)$ & 100.6 \\
\hline
\end{tabular}

Symmetry transformations used to generate equivalent atoms: $\# 1-x$, $-y,-z ; \# 2 x,-1 / 2-y, 1 / 2+z$

the $a$ axis with hydrogen bonds indicated by dotted lines is shown; the network formed by hydrogen bonds and the $\pi$-stacking interactions are visible.

\section{Electronic structure}

To gain insight into the electronic structures and bonding properties of these complexes, DFT calculations were carried out. Before the calculations of electronic structures of the complexes, their geometries were optimized in triplet states using the B3LYP functional. From the data collected in Table 2, one may see that the bond lengths are maximally elongated by $\sim 0.11 \AA$ in the calculated gasphase structures, while the bond angles almost unchanged. Figure 3 shows that the calculated and experimental IR spectra of complex $\mathbf{3}$ are in good agreement.

The formal charge of palladium is +2 in the complexes. The calculated charges on the palladium atoms, obtained from natural population analysis, are 0.04 in $\mathbf{1}, 0.30$ in $\mathbf{2}$, 0.19 in 3, 0.24 in complex $\mathbf{4}$, and 0.21 in $\mathbf{5}$. This is a result of charge donation from the ligands to the metal center and also shows that 2-hydroxy-6-methylpyridine is the strongest $\sigma$-donor among the ligands used.

The calculations utilize both $\alpha$ and $\beta$ occupied molecular orbitals. Among the occupied MOs of the complexes, the largest numbers constitute orbitals of the pyridine-type

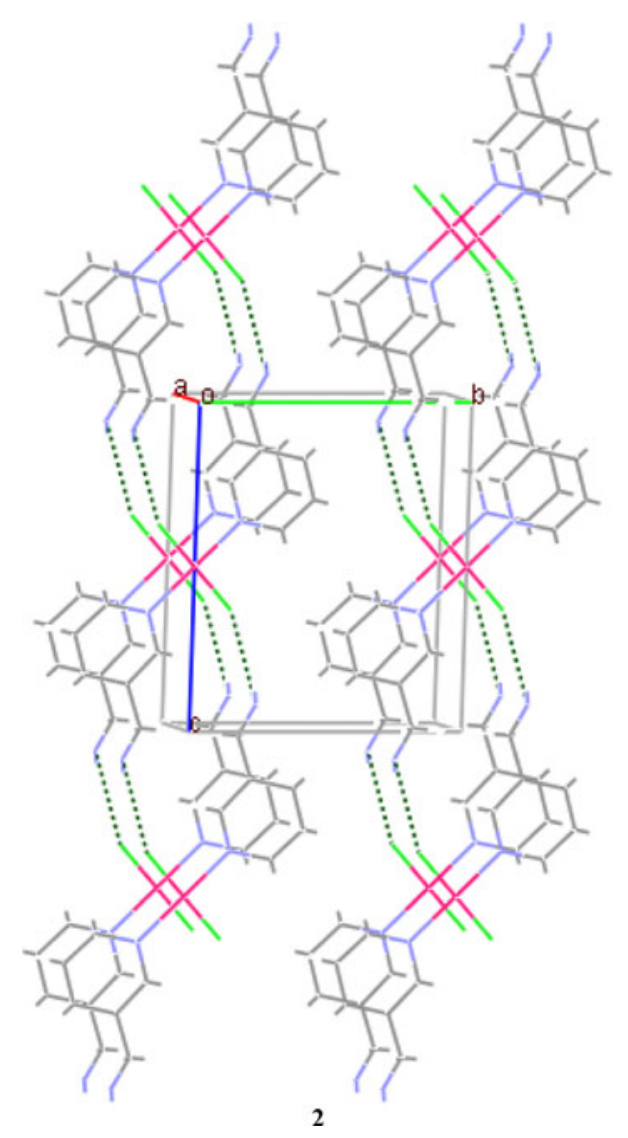

Fig. 2 Crystal packing of complex 2 viewing down the $a$ axis with hydrogen bonds indicated by dotted lines

ligands that are not relevant for the discussion. The $d_{y z}, d_{z^{2}}$, $d_{z x}$ orbitals of palladium(II) contribute to the HOMOs and in the range from HOMO-1 to HOMO-7 with $\alpha$ spin and in the HOMO-1 (2, 3, 4), HOMO-2/-3/-4 and HOMO-7/$8 /-9$ with $\beta$ spin. These molecular orbitals are mixed with $\pi$ orbitals of the pyridine derivatives and chloride ligands. The $d_{x y}$ and $d_{x^{2}-y^{2}}$ orbitals are visible in the LUMO and LUMO +1 orbitals with $\beta$ spin, with an antibonding admixture of pyridine and chloride orbitals.

In the frontier region, neighboring orbitals may show a quasi-degeneracy of the energy levels. In such cases, 


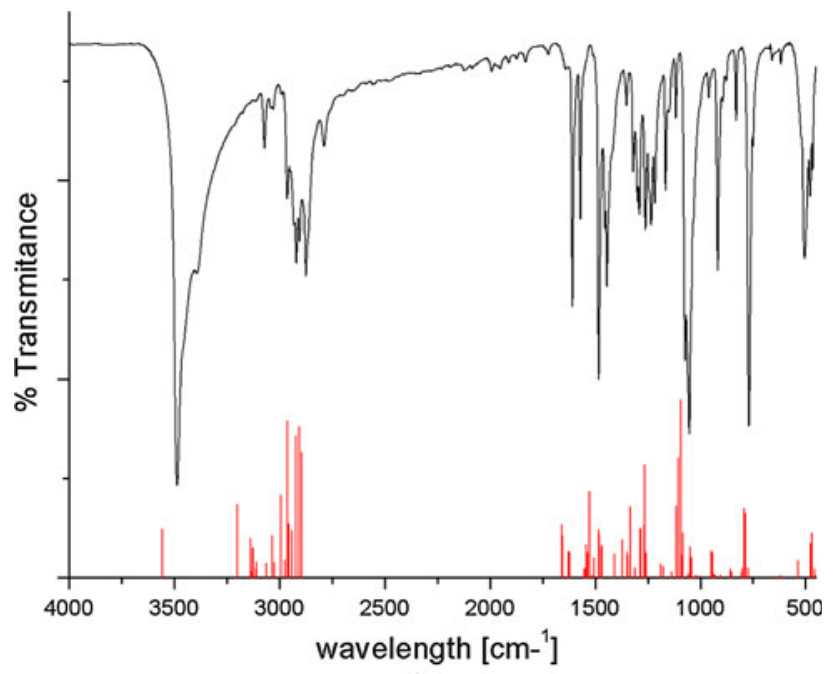

3

Fig. 3 The calculated frequencies and experimental IR spectrum of complex (3)

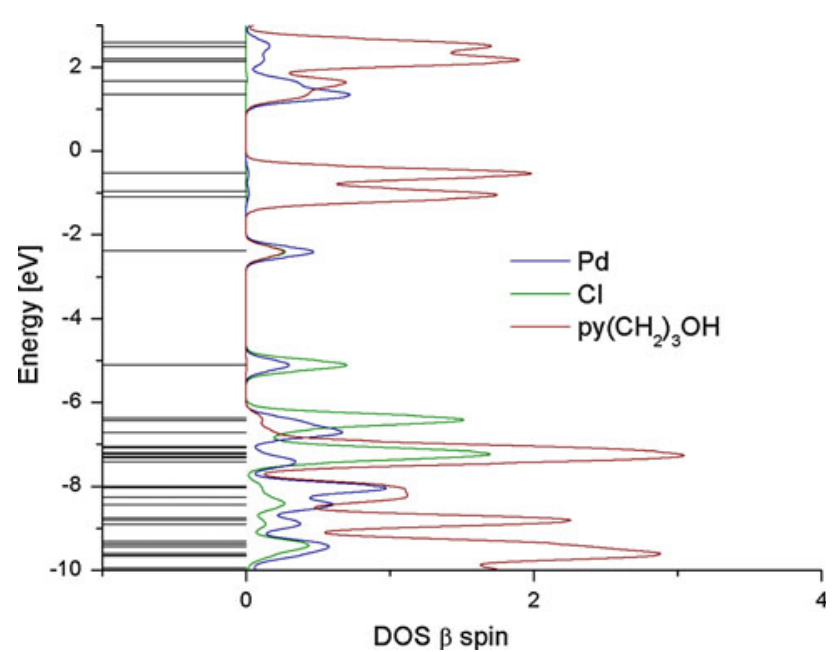

Fig. 4 The density of states ( $\beta$ spin DOS) diagram for $\left[\mathrm{PdCl}_{2}\right.$ $\left(\mathrm{CH}_{3} \text { pyOH }\right)_{2}$ ] (1) complex

consideration of only the HOMO and LUMO may not yield a realistic description of the frontier orbitals. For this reason, partial density of states (DOS) and overlap population density of states (OPDOS) in terms of Mulliken population analysis were calculated using the GaussSum program. They provide a pictorial representation of the MO compositions and their contributions to chemical bonding. The DOS diagram ( $\beta$ spin) for complex $\mathbf{3}$ is shown in Fig. 4 as an example. The DOS plot mainly presents the composition of the fragment orbitals contributing to the molecular orbitals. As may be seen from the DOS plots, the HOMO has $d_{P d}$ and $p_{C l}$ character and the LUMO is composed of $d$ palladium and $\pi^{*}$ orbitals of the pyridine ligands. The OPDOS gives an indication of the bonding, nonbonding, and antibonding characteristics with respect to the particular fragments. A

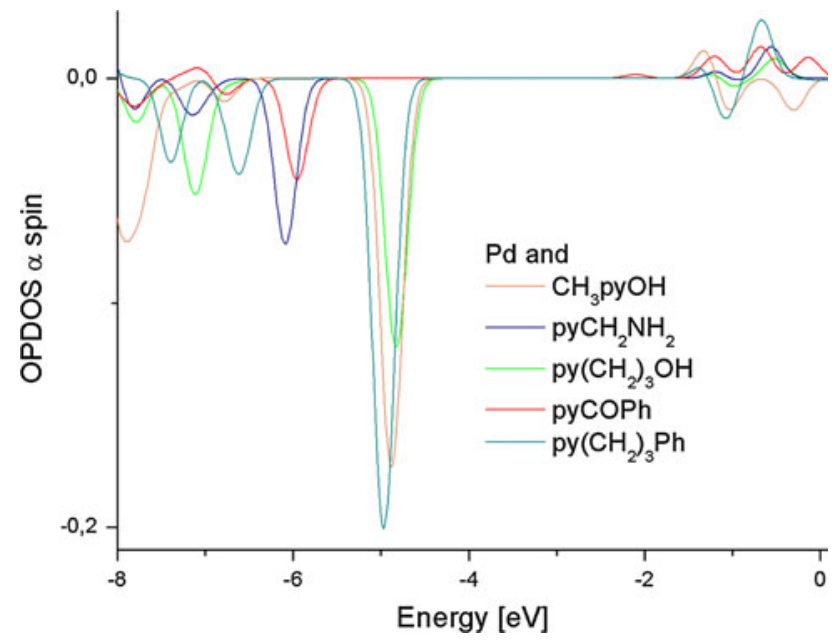

Fig. 5 Interaction between $\mathrm{Pd}(\mathrm{II})$ central ions and pyridine derivative ligands on the overlap partial density of states (OPDOS) diagrams for the complexes
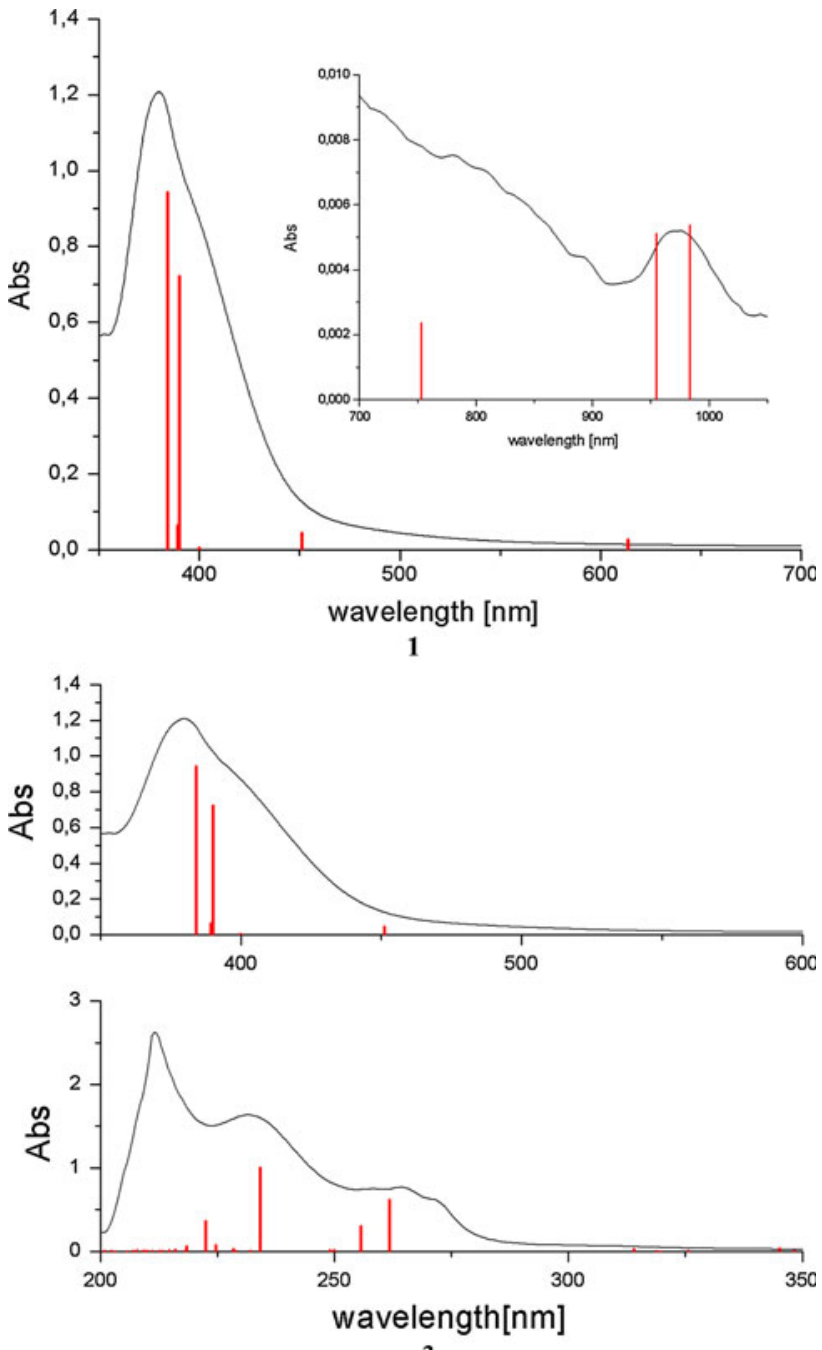

Fig. 6 UV-Vis spectra with calculated transitions for complexes (1) and (3) 
Table 4 Calculated electronic transitions for complexes 1, 2, 3, 4, and 5 with the TDDFT method

\begin{tabular}{|c|c|c|c|}
\hline$\lambda[\mathrm{nm}]$ & Contributions & $f$ & $\begin{array}{l}\text { Experimental } \\
\lambda[\mathrm{nm}](\log \varepsilon)\end{array}$ \\
\hline \multicolumn{4}{|c|}{$\left[\mathrm{PdCl}_{2}\left(\mathrm{CH}_{3} \mathrm{pyOH}\right)_{2}\right](1)$} \\
\hline 441.4 & $\mathrm{H}-8(\beta) \rightarrow \operatorname{LUMO}(\beta)(93 \%)$ & 0.0021 & \multirow[t]{4}{*}{$417(1.21)$} \\
\hline 393.5 & $\mathrm{H}-13(\beta) \rightarrow \operatorname{LUMO}(\beta)(98 \%)$ & 0.0106 & \\
\hline 373.3 & $\operatorname{HOMO}(\beta) \rightarrow \mathrm{L}+1(\beta)(100 \%)$ & 0.0019 & \\
\hline 347.2 & $\mathrm{H}-3(\beta) \rightarrow \mathrm{L}+1(\beta)(100 \%)$ & 0.0019 & \\
\hline 320.4 & $\mathrm{H}-4(\beta) \rightarrow \mathrm{L}+1(\beta)(93 \%)$ & 0.0312 & \multirow[t]{2}{*}{$305(2.14)$} \\
\hline 290.0 & $\mathrm{H}-20(\beta) \rightarrow \operatorname{LUMO}(\beta)(90 \%)$ & 0.0113 & \\
\hline 281.3 & $\mathrm{H}-20(\beta) \rightarrow \operatorname{LUMO}(\beta)(10 \%) ; \mathrm{H}-7(\beta) \rightarrow \mathrm{L}+1(\beta)(84 \%)$ & 0.2015 & $280(2.21)$ \\
\hline 249.6 & $\begin{array}{l}\mathrm{H}-2(\alpha) \rightarrow \operatorname{LUMO}(\alpha)(28 \%) ; \operatorname{HOMO}(\alpha) \rightarrow \mathrm{L}+4(\alpha) \\
\quad(15 \%) ; \mathrm{H}-1(\beta) \rightarrow \mathrm{L}+2(\beta)(33 \%)\end{array}$ & 0.1829 & \multirow[t]{3}{*}{$236(4.87)$} \\
\hline 232.0 & $\mathrm{H}-2(\beta) \rightarrow \mathrm{L}+2(\beta)(93 \%)$ & 0.0192 & \\
\hline 211.0 & $\mathrm{H}-6(\beta) \rightarrow \mathrm{L}+2(\beta)(12 \%) ; \mathrm{H}-4(\beta) \rightarrow \mathrm{L}+3(\beta)(30 \%)$ & 0.007 & \\
\hline 205.7 & $\begin{array}{l}\mathrm{H}-1(\alpha) \rightarrow \mathrm{L}+2(\alpha)(12 \%) ; \mathrm{H}-29(\beta) \rightarrow \operatorname{LUMO}(\beta)(31 \%) \\
\operatorname{HOMO}(\beta) \rightarrow \mathrm{L}+4(\beta)(16 \%)\end{array}$ & 0.0113 & $202(4.37)$ \\
\hline \multicolumn{4}{|c|}{$\left[\mathrm{PdCl}_{2}\left(\mathrm{pyCH}_{2} \mathrm{NH}_{2}\right)_{2}\right]$} \\
\hline 374.1 & $\mathrm{H}-8(\beta) \rightarrow \mathrm{L}+1(\beta)(94 \%)$ & 0.018 & \multirow[t]{2}{*}{$370(1.98)$} \\
\hline 329.1 & $\mathrm{H}-11(\beta) \rightarrow \mathrm{L}+1(\beta)(48 \%)$ & 0.293 & \\
\hline 320.6 & $\mathrm{H}-6(\alpha) \rightarrow \mathrm{L}+3(\alpha)(11 \%) ; \mathrm{H}-5(\alpha) \rightarrow \mathrm{L}+2(\alpha)(11 \%)$ & 0.026 & \multirow[t]{4}{*}{$319(2.17)$} \\
\hline 317.4 & $\mathrm{H}-17(\beta) \rightarrow \operatorname{LUMO}(\beta)(88 \%)$ & 0.071 & \\
\hline 287.5 & $\operatorname{HOMO}(\beta) \rightarrow \mathrm{L}+2(\beta)(61 \%)$ & 0.020 & \\
\hline 281.1 & $\mathrm{H}-15(\beta) \rightarrow \mathrm{L}+1(\beta)(56 \%) ; \mathrm{HOMO}(\beta) \rightarrow \mathrm{L}+2(\beta)(35 \%)$ & 0.069 & \\
\hline 271.6 & $\mathrm{H}-14(\beta) \rightarrow \mathrm{L}+1(\beta)(72 \%)$ & 0.027 & $255(4.75)$ \\
\hline \multicolumn{4}{|c|}{$\left[\mathrm{PdCl}_{2}\left(\mathrm{py}\left(\mathrm{CH}_{2}\right)_{3} \mathrm{OH}\right)_{2}\right](3)$} \\
\hline 388.9 & $\mathrm{H}-3(\beta) \rightarrow \mathrm{L}+1(\beta)(69 \%) ; \operatorname{HOMO}(\beta) \rightarrow \mathrm{L}+1(\beta)(26 \%)$ & 0.0045 & \multirow[t]{2}{*}{$392(1.83)$} \\
\hline 364.1 & $\mathrm{H}-6(\beta) \rightarrow \mathrm{L}+1(\beta)(35 \%) ; \operatorname{HOMO}(\beta) \rightarrow \mathrm{L}+1(\beta)(18 \%)$ & 0.0881 & \\
\hline 301.7 & $\mathrm{H}-8(\beta) \rightarrow \mathrm{L}+1(\beta)(92 \%)$ & 0.1927 & \multirow[t]{2}{*}{$317(2.06)$} \\
\hline 284.1 & $\mathrm{H}-10(\beta) \rightarrow \mathrm{L}+1(\beta)(93 \%)$ & 0.312 & \\
\hline 265.6 & $\mathrm{H}-11(\beta) \rightarrow \mathrm{L}+1(\beta)(94 \%)$ & 0.0933 & $264(3.96)$ \\
\hline 232.4 & $\mathrm{H}-2(\beta) \rightarrow \mathrm{L}+2(\beta)(23 \%)$ & 0.1118 & $232(4.13)$ \\
\hline 209.4 & $\mathrm{H}-8(\alpha) \rightarrow \operatorname{LUMO}(\alpha)(41 \%)$ & 0.0032 & $212(4.97)$ \\
\hline \multicolumn{4}{|c|}{$\left[\mathrm{PdCl}_{2}(\text { bopy })_{2}\right](4)$} \\
\hline 373.4 & $\mathrm{H}-12(\beta) \rightarrow \mathrm{L}+1(\beta)(74 \%)$ & 0.1124 & \multirow[t]{3}{*}{$370(1.62)$} \\
\hline 361.0 & $\mathrm{H}-14(\beta) \rightarrow \mathrm{L}+1(\beta)(83 \%)$ & 0.1586 & \\
\hline 285.3 & $\mathrm{H}-1(\alpha)->\mathrm{L}+1(\alpha)(21 \%) ; \mathrm{H}-4(\beta) \rightarrow \mathrm{L}+2(\beta)(21 \%)$ & 0.2007 & \\
\hline 275.7 & $\mathrm{H}-7(\beta) \rightarrow \mathrm{L}+2(\beta)(11 \%) ; \mathrm{H}-4(\beta) \rightarrow \mathrm{L}+2(\beta)(14 \%)$ & 0.0492 & \multirow[t]{2}{*}{$262(3.97)$} \\
\hline 257.4 & $\mathrm{H}-8(\alpha) \rightarrow \operatorname{LUMO}(\alpha)(16 \%) ; \mathrm{H}-8(\beta) \rightarrow \mathrm{L}+2(\beta)(25 \%)$ & 0.0539 & \\
\hline \multicolumn{4}{|c|}{$\left[\mathrm{PdCl}_{2}(\mathbf{p y C H P h})_{2}\right](5)$} \\
\hline 391.1 & $\mathrm{H}-6(\beta) \rightarrow \mathrm{L}+1(\beta)(69 \%)$ & 0.0321 & \multirow[t]{3}{*}{$377(1.23)$} \\
\hline 382.9 & $\mathrm{H}-12(\beta) \rightarrow \operatorname{LUMO}(\beta)(89 \%)$ & 0.1769 & \\
\hline 307.0 & $\mathrm{H}-5(\beta) \rightarrow \mathrm{L}+1(\beta)(45 \%)$ & 0.016 & \\
\hline 266.6 & $\mathrm{H}-13(\beta) \rightarrow \mathrm{L}+1(\beta)(38 \%)$ & 0.0969 & \multirow[t]{4}{*}{$285(2.96)$} \\
\hline 259.3 & $\mathrm{H}-9(\beta) \rightarrow \mathrm{L}+1(\beta)(85 \%)$ & 0.0126 & \\
\hline 245.6 & $\mathrm{H}-20(\beta) \rightarrow \mathrm{L}+1(\beta)(58 \%)$ & 0.0406 & \\
\hline 238.3 & $\mathrm{H}-25(\beta) \rightarrow \mathrm{L}+1(\beta)(48 \%)$ & 0.6217 & \\
\hline 206.7 & $\mathrm{H}-5(\alpha) \rightarrow \mathrm{L}+1(\alpha)(28 \%)$ & 0.5378 & \multirow[t]{2}{*}{$212(4.95)$} \\
\hline 200.9 & $\mathrm{H}-5(\alpha) \rightarrow \mathrm{L}+1(\alpha)(52 \%)$ & 0.1573 & \\
\hline
\end{tabular}


positive value in the OPDOS plot means a bonding interaction, while a negative value represents an antibonding interaction, and a near zero value indicates a nonbonding interaction. At the same time, an analysis of the OPDOS diagram allows us to determine the donor-acceptor properties of the ligands. From Fig. 5, it may be concluded that the 2-hydroxy-6-methyl-pyridine and 4-(3-phenylpropyl)pyridine ligands have comparable and strongest $\sigma$-donor and $\pi$-acceptor properties which is consistent with the charges on the palladium atoms given above. It is connected with an increase in energy of the HOMO associated with strong donor properties and strong $\pi$-acceptor ability of the ligand.

\section{Electronic spectra}

The UV-VIS spectra of the complexes are very similar. The nature of the transitions observed in the UV-Vis spectra has been analyzed using time-dependent DFT (TDDFT) based on the optimized triplet state geometry. The electronic transitions were calculated by use of the long range corrected version of the B3LYP functionalCAM-B3LYP which employs the Coulomb-attenuating method. This functional provides a better estimation of excitation energies and oscillators strengths, especially for transitions with Charge-Transfer character. Figure 6 presents the experimental spectra with the calculated transitions of complexes $\mathbf{3}$ and $\mathbf{5}$.

The calculations show that the longest wavelength experimental bands have a Charge-Transfer character connected with transitions from occupied orbitals localized on the pyridine derivatives ligands to $\beta$-spin LUMO, LUMO +1 orbitals localized on the $d_{x y}$ and $d_{x^{2}-y^{2}}$ palladium orbitals. In these bands, contributions of $\mathrm{d} \rightarrow \mathrm{d}$ transitions (LF) are also visible. For example, in the case of $\mathrm{H}-8(\beta) \rightarrow \mathrm{L}+1(\beta)(94 \%)$ transition in complex 2 , both occupied and virtual molecular orbitals are mainly composed of $d_{P d}$ orbitals. From the data collected in Table 4, one can see that the bands with maxima in the range 319-250 nm originate from transitions between lower occupied orbitals and the LUMO +1 . Therefore, these bands have CT character. The experimental bands with maxima near $200 \mathrm{~nm}$ are attributed to intraligand (IL) $\left(\pi_{(\mathrm{py})} \rightarrow \pi^{*}(\mathrm{py})\right)$ and ligand-ligand charge transfer $\left(\pi_{(\mathrm{Cl})} \rightarrow\right.$ $\left.\pi_{(\mathrm{py})}^{*}\right)$ transitions.

The emission properties of the complexes have been examined in methanol solutions (concentration of $5 \times$ $10^{-4} \mathrm{~mol} / \mathrm{dm}^{3}$ ) at room temperature. Figure 7 presents the emission spectra of complexes (2), (3), and (4). The excitations wavelengths were $390 \mathrm{~nm}$ for (3) and $370 \mathrm{~nm}$ for (2) and (4) which are the absorption maxima which may be assigned to a combination of $\mathrm{d} \rightarrow \mathrm{d}$, MLCT $\left(\mathrm{d} \pi_{(\mathrm{Pd})} \rightarrow\right.$ $\left.\pi_{\mathrm{py}}^{*}\right)$ and ${ }^{1} \mathrm{CILCT}\left(\mathrm{n}(\mathrm{Cl}) \rightarrow \pi^{*}\right)$ transitions. From the data collected in Table 4 and in the DOS diagrams, one may see that the pyridine ligands play similar role in the occupied and virtual frontier orbitals in all four complexes. Therefore, the emission originating from the lowest energy metal to ligand charge transfer (MLCT) state derived from the excitation involving a $\mathrm{d}_{\pi} \rightarrow \pi^{*}$ ligand transition is observed. This assignment is also supported by analysis of the frontier orbitals of the corresponding complexes that show a contribution from the ligands. The complicated structure of the luminescence spectra suggests that more than one state is involved in luminescence processes.
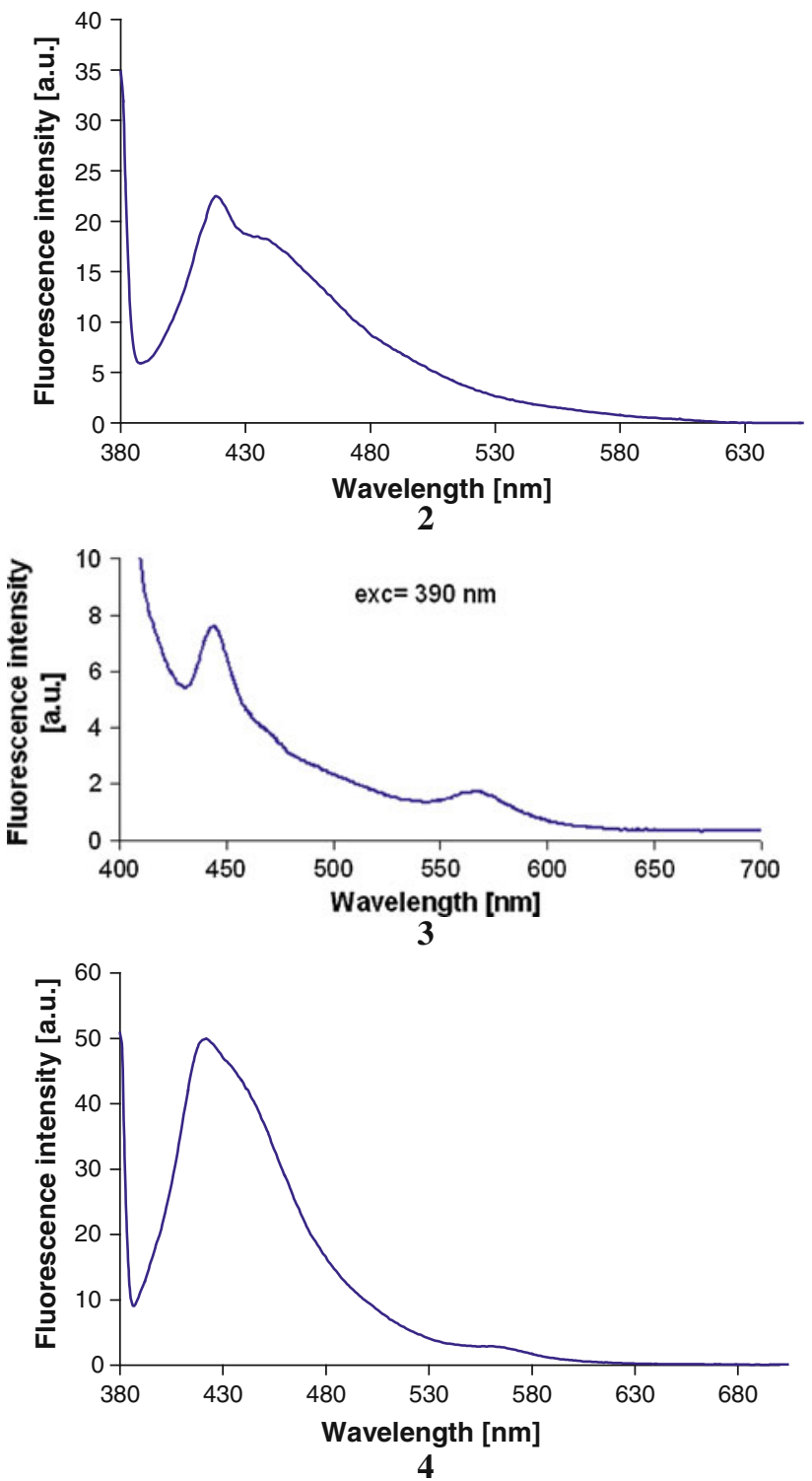

Fig. 7 Emission spectra of complexes (2), (3), and (4) in acetonitrile solutions $\left(\mathrm{c}=5.10^{-4} \mathrm{~mol} / \mathrm{dm}^{3}\right)$ 


\section{Conclusion}

Summarizing, new palladium(II) complexes with pyridine derivative ligands were synthesized. Molecular structures of the complexes were determined by X-ray, and the spectroscopic properties were studied. The crystal structures were used for DFT calculations in order to determine the electronic structures of the complexes. The results were used to compare $\pi$-donor/acceptor properties of the pyridine-type ligands. The electronic spectra were calculated with use of TD-DFT, and the transition characters were assigned in connection with the molecular orbitals of the complexes. The emission properties of the complexes were examined. The emissions originating from the lowest energy MLCT state derived from the excitation involving a $\mathrm{d}_{\pi} \rightarrow \pi^{*}$ ligand transition were observed. This assignment was supported by the analysis of the frontier orbitals of the corresponding complexes, showing a partial contribution from the ligands.

\section{Supplementary data}

CCDC 793379, CCDC 782336, CCDC 782033, CCDC 782241, and CCDC 794606 contain the supplementary crystallographic data for complexes $\left[\mathrm{PdCl}_{2}\left(\mathrm{CH}_{3} \text { pyOH }\right)_{2}\right]$ (1), $\left[\mathrm{PdCl}_{2}\left(\mathrm{pyCH}_{2} \mathrm{NH}_{2}\right)_{2}\right]$ (2), $\left[\mathrm{PdCl}_{2}\left(\mathrm{py}\left(\mathrm{CH}_{2}\right)_{3} \mathrm{OH}\right)_{2}\right]$ (3), $\left.\left[\mathrm{PdCl}_{2} \text { (bopy }\right)_{2}\right]$ (4), and $\left[\mathrm{PdCl}_{2}(\mathrm{pyCHPh})_{2}\right]$ (5), respectively. These data can be obtained free of charge from http://www.ccdc.cam.ac.uk/conts/retrieving.html or from the Cambridge Crystallographic Data Centre, 12 Union Road, Cambridge CB2 1EZ, UK; fax: (+44) 1223-336-033; or e-mail: deposit@ccdc.cam.ac.uk.

Acknowledgments The GAUSSIAN09 calculations were carried out in the Wrocław Centre for Networking and Supercomputing, WCSS, Wrocław, Poland (http://www.wcss.wroc.pl grant number 18).

Open Access This article is distributed under the terms of the Creative Commons Attribution Noncommercial License which permits any noncommercial use, distribution, and reproduction in any medium, provided the original author(s) and source are credited.

\section{References}

1. Kovala-Demertzi D, Demertzis MA, Filiou E, Pantazaki AA, Yadav PN, Miller JR, Zheng Y, Kyriakidis DA (2003) Biometals $16: 411$
2. Budizisz E, Krajewska U, Rozalski M, Szulawska A, Czyż M, Nawrot B (2004) Eur J Pharmacol 502:59

3. Kuduk-Jaworska J, Puszko A, Kibiak M, Pelczynska M (2004) J Inorg Biochem 98:1447

4. Budzisz E, Miernicka M, Lorenz I-P, Mayer P, Krajewska U, Rozalki M (2009) Polyhedron 28:637

5. Najajreh Y, Perez JM, Navarro-Ranninger C, Gibson D (2002) J Med Chem 45:5189

6. Khazanov E, Barenholtz Y, Gibson D, Najajreh Y (2002) J Med Chem 45:5196

7. Andrade-Lopez N, Alvarado-Rodriguez JG, Gonzalez-Montiel S, Rodriguez-Mendez MG, Paez-Hernandez ME, Galan-Vidal CA (2007) Polyhedron 26:4825

8. Ojwach SO, Guzei IA, Darkwa J, Mapolie SF (2007) Polyhedron 26:851

9. Liang H, Liu J, Li X, Li Y (2004) Polyhedron 23:1619

10. Piro NA, Owen JS, Bercaw JE (2004) Polyhedron 23:2797

11. Chen R, Bacsa J, Mapolie SF (2003) Polyhedron 22:2855

12. Anbalagan V, Srivastava TS (2004) Polyhedron 23:3173

13. Gaussian 09, Revision A.1, Frisch MJ, Trucks GW, Schlegel HB, Scuseria GE, Robb MA, Cheeseman JR, Scalmani G, Barone V, Mennucci B, Petersson GA, Nakatsuji H, Caricato M, Li X, Hratchian HP, Izmaylov AF, Bloino J, Zheng G, Sonnenberg JL, Hada M, Ehara M, Toyota K, Fukuda R, Hasegawa J, Ishida M, Nakajima T, Honda Y, Kitao O, Nakai H, Vreven T, Montgomery JA Jr., Peralta JE, Ogliaro F, Bearpark M, Heyd JJ, Brothers E, Kudin KN, Staroverov VN, Kobayashi R, Normand J, Raghavachari K, Rendell A, Burant JC, Iyengar SS, Tomasi J, Cossi M, Rega N, Millam JM, Klene M, Knox JE, Cross JB, Bakken V, Adamo C, Jaramillo J, Gomperts R, Stratmann RE, Yazyev O, Austin AJ, Cammi R, Pomelli C, Ochterski JW, Martin RL, Morokuma K, Zakrzewski VG, Voth GA, Salvador P, Dannenberg JJ, Dapprich S, Daniels AD, Farkas O, Foresman JB, Ortiz JV, Cioslowski J, Fox DJ (2009) Gaussian, Inc., Wallingford CT

14. Becke AD (1993) J Chem Phys 98:5648

15. Lee C, Yang W, Parr RG (1988) Phys Rev B 37:785

16. Casida ME (1996) In: Seminario JM (ed) Recent developments and applications of modern density functional theory, theoretical and computational chemistry, vol 4. Elsevier, Amsterdam, p 391

17. Yanai T, Tew D, Handy N (2004) Chem Phys Lett 393:51

18. Eichkorn K, Weigend F, Treutler O, Ahlrichs R (1997) Theor Chim Acc 97:119

19. Glendening ED, Reed AE, Carpenter JE, Weinhold F NBO (version 3.1)

20. O’Boyle NM, Tenderholt AL, Langner KM (2008) J Comp Chem 29:839

21. Dolomanov OV, Bourhis LJ, Gildea RJ, Howard JAK, Puschmann H (2009) J Appl Cryst 42:339

22. Sheldrick GM (1990) Acta Cryst A46:467

23. Sheldrick GM (1997) SHELXL97. Program for the solution and refinement of crystal structures. University of Göttingen, Germany 